\title{
Multiscale Modeling-Based Assessment of Elastic Properties of SLGS-Polymer Nanocomposites with Double-Atom Vacancy Defects
}

\author{
Z. Q. Wang, Z. W. Yu, X. Y. Sun, ${ }^{1}$ H. Li, and Y. J. Wang ${ }^{2}$ \\ College of Aerospace and Civil Engineering, Harbin Engineering University, Harbin, China \\ ${ }^{1}$ sunxiaoyu520634@163.com \\ $2906871278 @$ qq.com
}

УДК 539.4

\section{Расчет упругих свойств полимерных нанокомпозитов из однослойных листов графена с двойными атомарными вакансионными дефектами на основе мультимасштабного моделирования}

\author{
3. к. Ванг, 3. В. Ю, К. Я. Сун, Х. Ли, И. Ж. Ванг
}

Колледж аэрокосмического и гражданского строительства, Харбинский инженерный университет, Харбин, Китай

В рамках ранее предложенного авторами подхода на основе мультимасштабного моделирования исследуется влияние двойных атомарных вакансионных дефектов на упругие свойства полимерных нанокомпозитов из однослойных листов графена. Моделирование полимерной матрицы осуществляется методом конечных элементов, а интерфазный слой и однослойный лист графена моделируются на атомарном уровне в рамках молекулярной структурной механики. На основании концепции потенциала Леннарда-Джонса предполагается наличие зависимости ван дер Ваальса между свойствами однослойных листов графена и полимерной матрицы. Результаты численных расчетов показывают, что модуль упругости полимера можно увеличить в 17 раз за счет добавления 5\%-ной объемной доли однослойного листа графена. Установлено, что при увеличении количества двойных атомарных вакансионных дефектов модуль упругости полимерных композитов из однослойными листами графена снижается, в то время как с ростом объемной доли однослойных листов графена наблюдается его повымение.

Ключевые слова: графен, двойные атомарные вакансионные дефекты, упругие свойства, мультимасштабирование, нанокомпозит.

Introduction. Graphene is a new type of low-dimensional carbon material, which consists of carbon atoms in a honeycomb lattice structure. The latter provides high strength, high thermal conductivity and stiffness of graphene, as reported by numerous researchers [1-3]. The nanoindentation technology applied to graphene by Lee et al. [3] made it possible to evaluate its elastic properties using an inherent suspended graphene sheet (GS) and of a series of open holes on a Si substrate: the stress of $130 \mathrm{GPa}$ and elastic modulus of about $1 \mathrm{TPa}$ were attained. This finding strongly suggests that graphene is a perfect enhancing material for the next generation of composites.

The outstanding mechanical properties are demonstrated by nanocomposites based on polymer with exfoliated graphene sheets as enhancing factors have been demonstrated, e.g., by Rafiee et al. [4], who reported that inclusion of graphene sheets amounting to $1 \%$ of the composite weight resulted in significant improvement of its stiffness and the strength. As a 
reinforcement material, the magnitude's order obtains significance of the underlying benefits of graphene. For the GS weight fraction in the epoxy matrix equal to $0.1 \%$, the authors [5] have revealed the 52\%-increase in the nanocomposite buckling load value. In addition, the graphene fillers in the composite improved its resistance to fatigue crack propagation by almost two orders of magnitude, as compared with the base epoxy material [6].

In order to study the effect of GS presence on the polymer mechanical properties, the numerical simulation and theoretical studies have been conducted. By combining the Mori-Tanaka method [7] with the molecular mechanics approach, Cho et al. [8] investigated the mechanical properties of epoxy matrix reinforced with graphene sheets. The elastic modulus of the latter was calculated through the molecular force field approach, which formed the basis of the proposed micromechanical model. Awasthi et al. [9] investigated the nanoscale load transfer between a graphene sheet and polyethylene by applying the MD simulation. The further calculations strongly indicated that the nanocomposite elastic modulus varied with the GS aspect ratios, i.e., length-to-width relative values, rather than with their absolute values (sizes).

The effect of double-atom vacancy defects (DAVDs) on the elastic properties of single-layered graphene sheets (SLGS) has been estimated via a multiscale model in the recent study of the authors of this paper [10]. The same approach is applied in the present study to determine how the number of DAVDs affects the elastic properties of SLGSpolymer nanocomposites. For this purpose, the finite element (FE) approach is used to model the polymer matrix, while the molecular structural mechanics (MSM) is applied to the simulation of SLGS and interphase layer at the atomistic scale.

1. The Proposed Model. To establish a representative volume element (RVE) composed of a cubic body of the matrix with an embedded SLGS [16], a potential-based method is used, because the conventional theoretical frame is to assess the macroscopic mechanical properties of composites. This article forecasts the stable performance of SLGS-polymer composites with DAVDS in a similar way by a new MSM/FE multiscale modeling method with three stages. The components of the three-phase RVE are: the outer polymer matrix, the interphase, and the transition layer between the polymer matrix and graphene.

1.1. SLGS Model. Li and Chou [11] brought in the atomistic FEA approach, coined as the molecular structural mechanics (MSM) and implemented it via ANSYS commercial code to calculate the GSs elastic properties with account of vacancy-type defects. Since the detailed description of this approach can be found elsewhere $[10,11]$, only the minimal important details are given in this paper. Finite element nodes correspond to carbon atoms, and in the graphene sheet, the interatomic potentials between the covalently joint carbon atoms are modeled by the structural beams, in this method. Using continuous and discrete energy dependences linking the key effects of molecular mechanics related to torsion, bending, bond stretching and the consistent beam strain energies, the beams' elastic and geometric parameters are attained. Here $k_{\varphi}$ (torsion), $k_{r}$ (stretching), and $k_{\theta}$ (bending) interatomic force field constants can be interrelated with the beam geometric and elastic properties as follows:

$$
\begin{aligned}
& k_{r}=\frac{E_{\text {beam }} A}{L}, \\
& k_{\theta}=\frac{E_{\text {beam }} I}{L}, \\
& k_{\varphi}=\frac{G_{\text {beam }} J}{L},
\end{aligned}
$$


where $G_{\text {beam }}$ and $E_{\text {beam }}$ are the beam shear and elastic moduli, respectively, $J$ is the beam polar moment of inertia, $I$ is the beam moment of inertia, $L$ is the beam length (bond distance between carbon atoms), and $A$ is the cross-sectional area (which is presumed to have a circular shape. Equations (1)-(3) are constructed to derive the elastic properties of the beam factors and the effective diameter $d$ as follows:

$$
\begin{gathered}
d=4 \sqrt{\frac{k_{\theta}}{k_{r}}}, \\
E_{\text {beam }}=\frac{k_{r}^{2} L}{4 \pi k_{\theta}}, \\
G_{\text {beam }}=\frac{k_{r}^{2} k_{\varphi} L}{8 \pi k_{\theta}^{2}} .
\end{gathered}
$$

A C-C bond length of $L=0.1421 \mathrm{~nm}$ was applied in Eqs. (4)-(6) with $k_{\theta}=$ $=8.78 \cdot 10^{-10} \mathrm{~N} \cdot \mathrm{nm} / \mathrm{rad}^{2}, k_{r}=6.52 \cdot 10^{-7} \mathrm{~N} / \mathrm{nm}$, and $k_{\varphi}=2.78 \cdot 10^{-19} \mathrm{~N} \cdot \mathrm{m} / \mathrm{rad}^{2}$ for the purpose of computing the beam cross-sectional parameters, which yields the beam diameter $d=0.147 \mathrm{~nm}$, elastic modulus $E_{\text {beam }}=5.49 \mathrm{TPa}$, and shear modulus $G_{\text {beam }}=0.871 \mathrm{TPa}$. In addition, Poisson's ratio $v=0.3$ is assumed based on Fig. 1 demonstrates the numbers of the DAVDs from zero to seven and the SLGS with DAVDs investigated in this work.

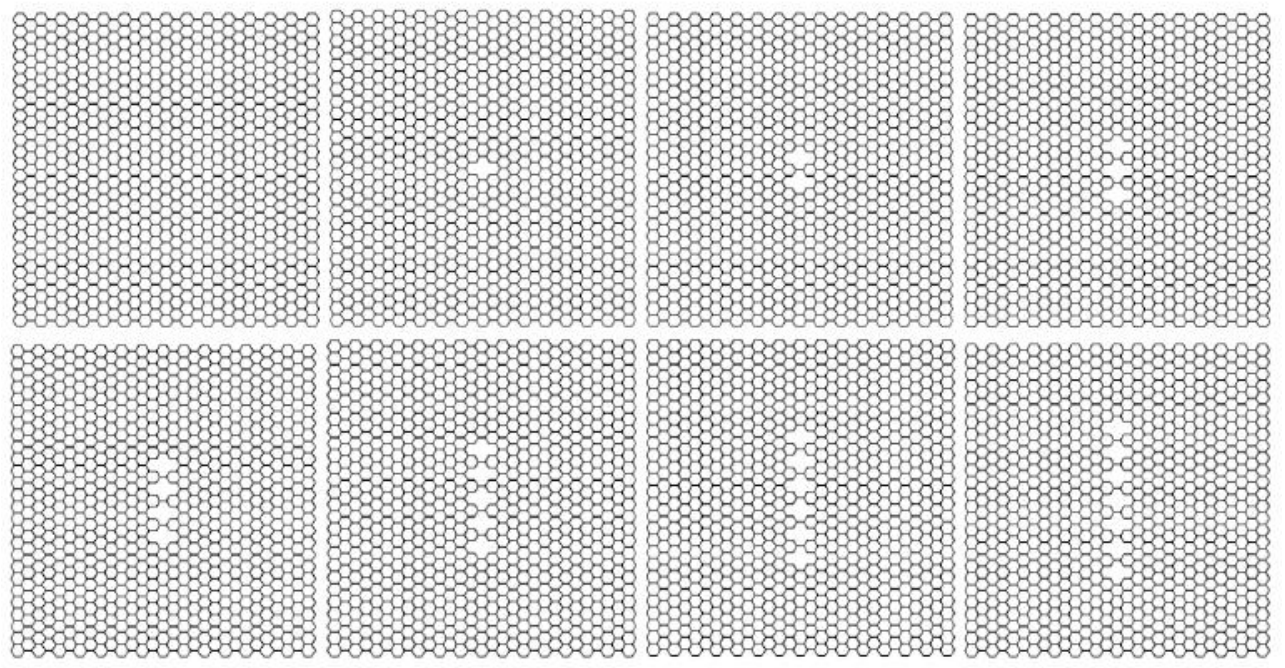

Fig. 1. SLGS with the number of DAVDs ranging from zero to seven.

1.2. Polymer Matrix Model. Continuum-based FE formulation plays an important part in analyzing the outer polymer matrix and the interphase layer. An isoparametric cubic factor, which is applied for modeling of the matrix, is defined by eight nodes with three degrees of freedom, each node including three translations in the $z, y$, and $x$ directions. Polymethyl methacrylate (PMMA) is the polymer matrix chosen in the research. It is presumed that the elastic modulus of this isotropic amorphous polymer is $2.5 \mathrm{GPa}$, in compliance with its experimental range between 3.8 and $2.24 \mathrm{GPa}$ attained in [12]. Poisson's ratio of 0.35 is used for the PMMA polymer matrix. 
1.3. Interphase Layer Model. The Lennard-Jones potential represents the SLGS and polymer matrix interactions, which correspond to $\mathrm{vdW}$ without a link:

$$
V_{L J}=4 \varepsilon\left[\left(\frac{\sigma}{r}\right)^{12}-\left(\frac{\sigma}{r}\right)^{6}\right],
$$

where $r$ is the interatomic distance, $\varepsilon$ and $\sigma$ represent the potential and the distance, respectively, between two balanced atoms. The values of $\sigma$ and $\varepsilon$ are $3.8655 \cdot 10^{-13} \mathrm{~N} / \mathrm{nm}$ and $0.34 \mathrm{~nm}$, respectively, as for carbon atoms. When the distance was shorter compared with the LJ potential's shortcut radius, an elastic beam element was used to simulate the $\mathrm{vdW}$ interaction equivalent to the extensive strain energy $U_{r}$, provided by Eq. (2) between $\mathrm{C}$ atoms of SLGS and $\mathrm{H}$ atoms of the polymer matrix. Thus, the respective equation can be derived as follows:

$$
V_{L J}=U_{r}=\frac{1}{2} k\left(r-r_{0}\right)^{2}
$$

The following equation can be obtained by expanding the Lennard-Jones potential into a Taylor series with the first two terms:

$$
k=4 \varepsilon\left(156 \frac{\sigma^{12}}{r^{14}}-42 \frac{\sigma^{6}}{r^{8}}\right) .
$$

Meanwhile, the force constant $k$ can be attained through Eq. (4) as follows:

$$
k=\frac{E A}{r} .
$$

For the earlier described beam section, the beam element radius amounts to $0.146618 \mathrm{~nm}$. By re-arranging Eqs. (9) and (10) and using Poisson's ratio of 0.3, we can attain the beam effective elastic modulus.

Poisson's ratio and the elastic modulus of the equivalent beam of SLGS, interphase and polymer matrix applied in the current work have been defined in our earlier work [11]. For the purpose of attaining the transition layer's thickness in a SLGS-polymer composite, $\mathrm{Hu}$ et al. carried out the molecular mechanics calculations, which yielded the equilibrium distance between $\mathrm{C}$ atoms of the nanotube and $\mathrm{H}$ atoms of the polymer from 0.2851 to $0.5445 \mathrm{~nm}$. The mean value of this range, i.e., $0.40 \mathrm{~nm}$, is used in our study as the transition layers thickness. The SLGS-polymer nanocomposites' multiscale model is demonstrated in Fig. 2.

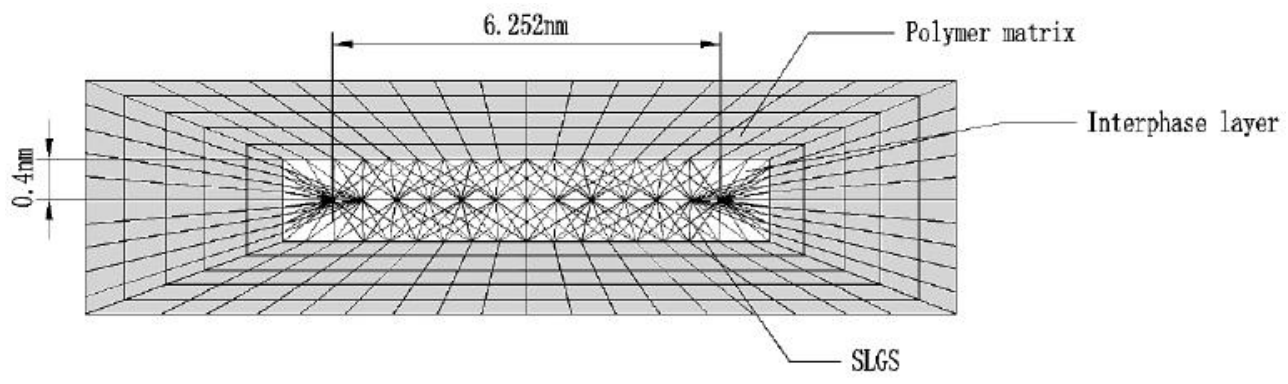

Fig. 2. The multiscale model of SLGS-polymer nanocomposite. 
The SLGS volume fraction $\left(f_{S L G S}\right)$ is an important variable in determining the composite mechanical properties and is defined as

$$
f_{S L G S}=\frac{\left(W_{S L G S}+2 h_{v d W}\right)\left(h_{S L G S}+2 h_{v d W}\right)}{A_{\text {cell }}},
$$

where $h_{v d W}$ is the thickness of the transition layer whose value is $0.40 \mathrm{~nm}, h_{S L G S}$ is the thickness of SLGS whose value is $0.34 \mathrm{~nm}, f_{S L G S}$ is SLGS volume fraction, $W_{S L G S}$ is the width of SLGS, and $A_{\text {cell }}$ is the unit cell's cross-sectional area. The RVE applied here is constant as mentioned before. Therefore, the polymer matrix is the same as the SLGS's length in this study, whose value is $6.399 \mathrm{~nm}$, and the width of SLGS $W_{S L G S}$ is $6.252 \mathrm{~nm}$. The input data containing the constituent properties are listed in Table 1. The elastic modulus of the nanocomposite was calculated as follows [10]:

$$
E=\frac{\sigma}{\varepsilon}=\frac{F / A_{\text {cell }}}{\Delta L / L},
$$

where $F$ is the total force(in units of $\mathrm{nN}$ ) applied to RVE edge, $\Delta L$ is the elongation of $\mathrm{RVE}$, and $L$ is the original length (in $\mathrm{nm}$ ).

T a b 1 e 1

Input Data for the FEA of SLGS-Polymer Nanocomposite

\begin{tabular}{|l|c||}
\hline \multicolumn{1}{|c|}{ Parameter } & Value \\
\hline Elastic modulus of equivalent beam of SLGS $\left[\mathrm{N} / \mathrm{nm}^{2}\right]$ & $5.488 \cdot 10^{-6}$ \\
\hline Elastic modulus of polymer matrix [GPa] & 2.5 \\
\hline Elastic modulus of interphase layer & Solve Eqs. (10) and (11) \\
\hline Poisson's ratio of the equivalent beam of SLGS & 0.3 \\
\hline Poisson's ratio of polymer matrix & 0.35 \\
\hline Poisson's ratio of interphase layer & 0.3 \\
\hline Length of SLGS [nm] & 6.399 \\
\hline Width of SLGS [nm] & 6.252 \\
\hline Thickness of SLGS [nm] & 0.34 \\
\hline Length of polymer matrix [nm] & 6.399 \\
\hline Thickness of interphase layer [nm] & 0.4 \\
\hline Cross-sectional area of the unit cell [nm $\left.{ }^{2}\right]$ & $8.039 / f_{S L G S}$ \\
\hline
\end{tabular}

2. Results and Discussion. The elastic modulus of SLGS-polymer nanocomposites is 42.5 $\mathrm{GPa}$, which is 17 times higher than that of purely polymer matrix when the SLGS volume fraction is $5 \%$. These results demonstrate that SLGS is a superior filler to improve the elastic property in nanocomposite. Although the experimental results corroborated the feasibility of the proposed multiscale model concerning SLGS's enhancement abilities, there are systematical deviations between the experimental data and numerical simulation results: the former are much lower than latter. These discrepancies can be attributed to: (i) the neglect of involvement of different SLGS layers in the load transfer; (ii) the wrinkled (wavy) structure of SLGS in the polymeric matrix, which is observed at different temperatures differs from a flat rectangular shape presumed in the model; (iii) DAVDs in SLGS reduce their mechanical properties; (iv) an arbitrary orientation of fibers in tests does not comply with the unidirectional one assumed in the numerical simulations. 
The effect of DAVDs number variation (from zero to seven) on the elastic properties of SLGS-polymer nanocomposites is depicted in Fig. 3. It is shown that the elastic modulus of defect-free SLGS-polymer nanocomposite drops down with an increase in the number of DAVDs by a linear correlation, namely by approx. 5.8\% per defect. As seen from Fig. 3, the elastic modulus of SLGS-polymer nanocomposites exhibits a linear deterioration trend with the SLGS volume fraction: 1\%-reduction of SLGS volume fraction results in a $10.6 \%$-drop of the elastic properties of SLGS-polymer nanocomposite.

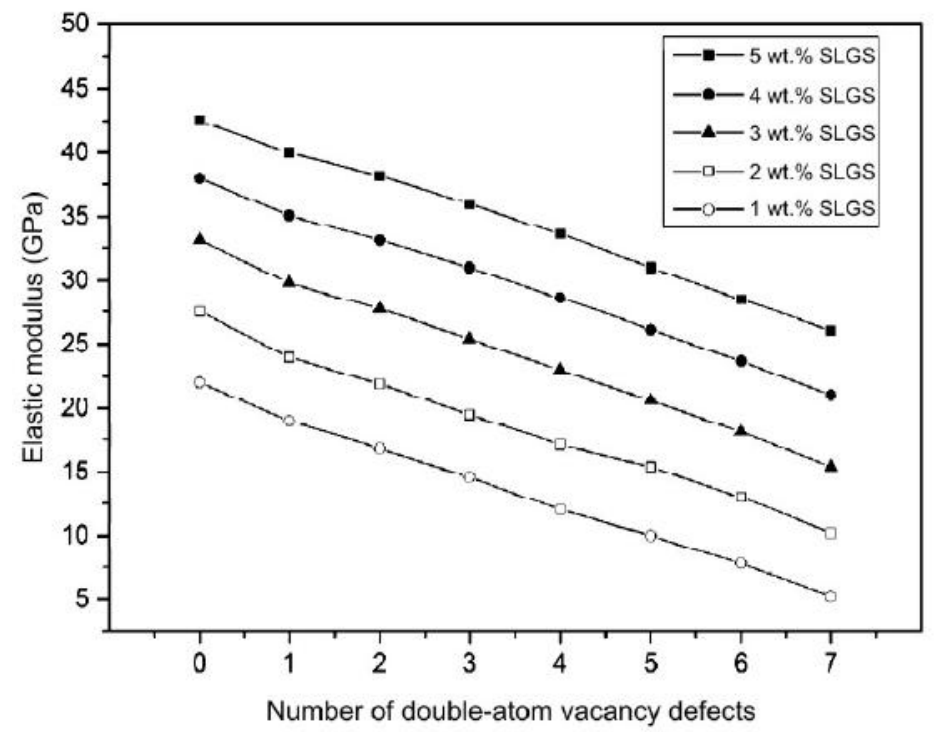

Fig. 3. The elastic modulus of SLGS-polymer nanocomposites with different SLGS volume fraction versus the number of DAVDs (varying from zero to seven).

Conclusions. The effect of double-atom vacancy defects (DAVDs) on the elastic properties of single-layered graphene sheets (SLGS)-polymer nanocomposites, is assessed by the proposed multiscale model.

It is shown that the elastic modulus of defect-free SLGS-polymer nanocomposite drops down with an increase in the number of DAVDs by a linear correlation, namely by approx. 5.8\% per defect. As seen from Fig. 3, the elastic modulus of SLGS-polymer nanocomposites exhibits a linear deterioration trend with the SLGS volume fraction: $1 \%$-reduction of SLGS volume fraction results in a $10.6 \%$-drop of the elastic properties of SLGS-polymer nanocomposite.

The limitations of the proposed approach, which resulted in systematic overestimation of the elastic modulus, can be reduced to: (i) the neglect of involvement of different SLGS layers in the load transfer; (ii) the wrinkled (wavy) structure of SLGS in the polymeric matrix, which is observed at different temperatures differs from a flat rectangular shape presumed in the model; (iii) DAVDs in SLGS reduce their mechanical properties; (iv) an arbitrary orientation of fibers in tests does not comply with the unidirectional one assumed in the numerical simulations.

The above problematic issues are envisaged to be tackled in the further theoretical and numerical simulation studies.

Acknowledgments. This work was supported by the National Natural Science foundation of China (Nos. 11602066, 11472086, and 11532013) and the National Science Foundation of Heilongjiang Province of China (QC2015058 and 42400621-1-15047), the Foundation Research Funds for the Central Universities. 


\section{Резюме}

У рамках раніше запропонованого авторами підходу на основі мультимасштабного моделювання досліджується вплив подвійних атомарних вакансійних дефектів на пружні властивості полімерних нанокомпозитів з одношарових листів графена. Моделювання полімерної матриці виконано методом скінченних елементів, а інтерфазний шар і одношаровий лист графена моделюються на атомарному рівні в рамках молекулярної структурної механіки. На основі концепції потенціалу Леннарда-Джонса припускається наявність залежності ван дер Ваальса між властивостями одношарових листів графена і полімерної матриці. Результати чисельних розрахунків показують, що модуль пружності полімеру можна збільшити в 17 разів за рахунок додання 5\%-ної об'ємної частки одношарового листа графена. Установлено, що з ростом кількості подвійних атомарних вакансійних дефектів модуль пружності полімерних композитів з одношаровими листами графена зменшується, в той час як зі зростанням об’ємної частки одношарових листів графена відмічається його підвищення.

1. K. S. Novoselov, A. K. Geim, S. V. Morozov, et al., "Electric field effect in atomically thin carbon films," Science, 306, Issue 5696, 666-669 (2004).

2. A. P. Yu, M. E. Itkis, E. Bekyarova, and R. C. Haddon, "Nanoplatelet-epoxy composite thermal interface materials," J. Phys. Chem. C, 111, No. 21, 7565-7571 (2007).

3. C. Lee, X. D. Wei, J. W. Kysar, and J. Hone, "Measurement of the elastic properties and intrinsic strength of monolayer graphene," Science, 321, Issue 5887, 385-388 (2008).

4. M. A. Rafiee, J. Rafiee, Z. Wang, et al., "Enhanced mechanical properties of nanocomposites at low graphene content," ACS Nano, 3, No. 12, 3884-3890 (2009).

5. M. A. Rafiee, J. Rafiee, Z.-Z. Yu, and N. Koratkar, "Buckling resistant graphene nanocomposites," Appl. Phys. Lett., 95, No. 22, 223103 (2009).

6. M. A. Rafiee, J. Rafiee, I. Srivastava, et al., "Fracture and fatigue in graphene nanocomposites," Small, 6, No. 2, 179-183 (2010).

7. T. Mori and K. Tanaka, "Average stress in matrix and average elastic energy of materials with misfitting inclusions," Acta Metall., 21, No. 5, 571-574 (1973).

8. J. Cho, J. J. Luo, and I. M. Daniel, "Mechanical characterization of graphite/epoxy nanocomposites by multi-scale analysis," Compos. Sci. Technol., 67, Nos. 11-12, 2399-2407 (2007).

9. A. P. Awasthi, D. C. Lagoudas, and D. C. Hammerand, "Modeling of graphenepolymer interfacial mechanical behavior using molecular dynamics," Model. Simul. Mater. Sci. Eng., 17, No. 1, 015002 (2009).

10. Z. Q. Wang, Z. W. Yu, X. Y. Sun, et al., "Effect of double-atom vacancy defects on the elastic properties of single-layered graphene sheets," Strength Mater., 49, No. 6, 865-871 (2017).

11. C. Li and T. W. Chou, "A structural mechanics approach for the analysis of carbon nanotubes," Int. J. Solids Struct., 40, No. 10, 2487-2499 (2003).

12. Y. Zhu, T. Yi, B. Zheng, and L. Cao, "The interaction of C60 fullerene and carbon nanotube with Ar ion beam," Appl. Surf. Sci., 137, Nos. 1-4, 83-89 (1999). 